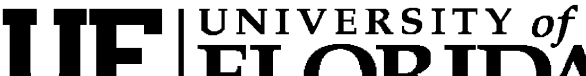 FLORIDA \\ IFAS Extension
}

\section{YOU and YOUR CREDIT: Further Resources ${ }^{1}$}

\author{
Michael S. Gutter, Joan P. Elmore, and Travis P. Mountain ${ }^{2}$
}

Below are links to each of the YOU and YOUR CREDIT series.

Credit Dos and Don'ts: PDF version - http://edis.ifas.ufl.edu/pdffiles/FY/FY106400.pdf

Credit Card Basics: PDF version - http://edis.ifas.ufl.edu/pdffiles/FY/FY106500.pdf

Managing Your Credit: PDF version - http://edis.ifas.ufl.edu/pdffiles/FY/FY106700.pdf

Credit Scores: PDF version - http://edis.ifas.ufl.edu/pdffiles/FY/FY106800.pdf

Home Ownership and Credit: PDF version - http://edis.ifas.ufl.edu/pdffiles/FY/FY106900.pdf

Further Resources: PDF version - http://edis.ifas.ufl.edu/pdffiles/FY/FY107000.pdf

Series of Five Parts, Bound as Single Document: PDF version -

http://edis.ifas.ufl.edu/pdffiles/FY/FY107100.pdf

1. This document is FCS7235, one of a series of the Department of Family, Youth, and Community Sciences, Florida Cooperative Extension Service, Institute of Food and Agricultural Sciences, University of Florida. Original publication date September 22, 2008. Visit the EDIS Web site at http://edis.ifas.ufl.edu.

2. Michael S. Gutter, Financial Management State Specialist and Assistant Professor, Department of Family, Youth, and Community Sciences, Institute of Food and Agricultural Sciences, University of Florida, Gainesville, Florida 32611; Joan P. Elmore, Extension Agent IV, Jackson County Extension, Marianna, Florida 32448; and, Travis P. Mountain, Lecturer, Department of Family, Youth, and Community Sciences, Institute of Food and Agricultural Sciences, University of Florida, Gainesville, Florida 32611

The Institute of Food and Agricultural Sciences (IFAS) is an Equal Opportunity Institution authorized to provide research, educational information and other services only to individuals and institutions that function with non-discrimination with respect to race, creed, color, religion, age, disability, sex, sexual orientation, marital status, national origin, political opinions or affiliations. U.S. Department of Agriculture, Cooperative Extension Service, University of Florida, IFAS, Florida A. \& M. University Cooperative Extension Program, and Boards of County Commissioners Cooperating. Larry Arrington, Dean 


\section{YOU and YOUR CREDIT: Further Resources ${ }^{1}$}

Michael S. Gutter, Financial Management State Specialist, IFAS/UF, Joan P. Elmore, Extension Agent IV, Jackson County Extension, Marianna, Florida 32448, Travis P. Mountain, Lecturer, IFAS/UF ${ }^{2}$

\section{To learn more, visit your local library/county extension office and check out the following resources:}

You and YOUR Credit, Joan Elmore, Extension Agent IV, University of Florida, Jackson County Extension, 2007

Bankrate, Credit Management, 2007

Money Smart, Federal Deposit Insurance Commission, 2006

Building a Better Credit Report, Federal Trade Commission, 2004

Making Money Work for You, University of New Hampshire Extension, March 2002

Winning the Credit Game, University of Florida Extension, M. Harrison, 2002

Show Me the Money, Lesson3: Using Credit Wisely, Dr. J Turner, University of Florida

Extension, 2001

Dealing with Dollars, Joan Elmore, Extension Agent IV, University of Florida, Jackson County Extension, 2001

1. This document is FCS7235, one of a series of the Department of Family, Youth and Community Sciences, Florida Cooperative Extension Service, Institute of Food and Agricultural Sciences, University of Florida. First published: September 2008. Please visit the EDIS Web site at http://edis.ifas.ufl.edu.

2. Michael S. Gutter, Financial Management State Specialist, IFAS/UF, Joan P. Elmore, Extension Agent IV, Jackson County Extension, Marianna, Florida 32448, Travis P. Mountain, Lecturer, IFAS/UF. 